\title{
Polymorphism of CSN1S1 (g.12164G>A) and CSN2 (g.8913C $>A)$ genes in pure and cross dairy goats
}

\author{
Anneke Anggraeni ${ }^{*}$, Lailatus Syifa ${ }^{2}$, Oktiq Kurnia Sari ${ }^{2}$, Andi Baso Lompengeng Ishak ${ }^{1}$, \\ and Cece Sumantri ${ }^{2}$ \\ ${ }^{1}$ Indonesian Research Institute for Animal Production (IRIAP), PO Box 221 Ciawi, Bogor, Indonesia \\ ${ }^{2}$ Faculty of Animal Science, Bogor Agriculture University, Bogor, Indonesia
}

\begin{abstract}
Casein genes directly control milk protein of animals. CSN1S1 ( $\alpha$ S1-Casein) and CSN2 ( $\beta$-Casein) genes influence on milk protein fractions. Genetic polymorphisms of CSN1S1 gene at g.12164G > A locus and CSN2 gene at g. 8913C > A locus were identified by PCR-RFLP technique. Animal samples were pure dairy goats providing PE (5 hds.), Saanen ( 8 hds.) and their crosses providing Sapera (50\% Saanen, 50\% PE) (51 hds.) and SaanPE (75\% Saanen, 25\% PE) (3 hds.) from IRIAP dairy goat station. Allele frequency, genotype frequency, heterozygosity value, and Hardy-Weinberg $(\mathrm{H}-\mathrm{W})$ equilibrium value were analyzed by Popgen32 program. CSN1S1_g.12164G>A locus resulted in two alleles, i.e. G allele (192 bp, $145 \mathrm{bp}$, and $101 \mathrm{bp}$ ) and A allele (337 bp and $101 \mathrm{bp}$ ). The $\mathrm{G}$ allele from the highest frequenciest was successively Saanen (0.625), Sapera (0.578), PE (0.400), and SaanPE (0.333). Most dairy goats were heterozygote $(\mathrm{Ho}>\mathrm{He})$ and in $\mathrm{H}-\mathrm{W}$ equilibrium $\left(\mathrm{q}^{2}\right.$ count $<$ $\left.\mathrm{q}^{2} \mathrm{P} 0.05\right)$. Whereas CSN2_g.8913C $>\mathrm{A}$ locus was monomorphic for possesing only $\mathrm{C}$ allele (233 bp and $162 \mathrm{bp}$ ), without A allele (416 bp). The existent g.12164G>A SNP of the CSN1S1 gene of could be a potencial molecular selection marker of milk protein content in dairy goat. Keywords: Dairy goats, CSN1S1 gene, CSN2 gene, genetic polymorphism
\end{abstract}

\section{Introduction}

Milk yield and its quality are essential factors for national dairy development. Dairy goat is one of small ruminants that is quite adaptive to tropical climatic condition. Beside of dairy cattle, dairy goat can be positioned as a good producer to produce milk [1]. Milk protein is the main precursor of bioactive peptides which play an essential role in biological regulation due to its function as antihypertensive, antioxidant, antimicrobial, immunomodulatory and mineral binding [2]. Milk protein from ruminants consists of two main components, namely casein and whey $[3,4,5]$. Casein represents about $80 \%$ of the total milk protein contents [6]. Milk of dairy cattle contains about 3.5\% protein consisting

\footnotetext{
* Corresponding author : ria.anneke@yahoo.co.id
} 
of casein by $78-82 \%$ and whey by $18-22 \%$ [5]. Casein fraction plays an essential role as a peptide bioactive. Casein in milk is found as suspension particles from casein miscelles and dairy products such as yogurt, cheese and ice cream [7].

Milk casein fractions were determined by four casein genes, namely $\alpha \mathrm{S} 1$-casein (CSN1S1), $\beta$-casein (CSN2), $\alpha$ S2-casein (CSN1S2), and $\kappa$-casein (CSN3) [3, 5, 8, 9]. These casein gene complexes were located closely about $250 \mathrm{~kb}$ at chromosome 6 which are very commonly inherited as haplotype [8, 10, 11, 12]. The as1-Casein gene or CSN1S1 gene in goat had $16.5 \mathrm{~kb}$ of transcriptions units consisting of 19 exons, with variation in the base lengths from $24 \mathrm{bp}$ to $358 \mathrm{bp}$, and having 18 introns [13]. The CSN1S1 gene expressed the highest level of polymorphism compared to the other three casein genes [14]. This gene had a direct effect on quality, character, and composition of milk [15]. The presence of a base mutation in exon 12 at CSN1S1 gene at g.12164G>A locus resulted in the B3 allele (Cozenza et al, 2008). Further $\beta$-casein gene or CSN2 gene presented a base length about $10.7 \mathrm{~kb}$ consisting of 9 exons [16]. The $\beta$-casein was a phosphoprotein sensitive to calcium [17]. In goat, autosomal alleles including A, A1, C, $\mathrm{C} 1, \mathrm{E}$, and 0 were characterized at DNA levels, while B and D alleles were characterized at protein levels [18]. The presence of a base mutation in exon 7 at the CSN2 gene at g.8913C > A locus resulted in E allele being responsible for the changes of the amino acid of Ser166 to Tyr166 in complete protein [19].

Exploration of genetic variants of the CSN1S1 gene has been carried out in Saanen goat $[6,7]$. While genetic polymorphisms of the CSN2 gene have been reported, among others, in cattle [14, 20], sheep, buffalo, and yaks [21]. Studies on genetic polymorphisms of CSN1S1 and CSN2 genes need to be explored in local PE dairy goat and its crosses to exotic Saanen dairy goat that could be useful genetic informations to be considered as molecular selection tool in achieving genetic improvement of milk production and milk protein contents of these pure and crosses dairy goats.

\section{Materials and Methods}

\subsection{Location and Period of Research}

Observation and collection of blood samples of dairy goats were conducted at IRIAP (Indonesian Researh Institute for Animal Production) dairy goat Station, Ciawi, Bogor. Extraction and genotyping DNA samples were carried out at the Laboratory of Animal Molecular Genetic, Department of Animal Production and Technology, Faculty of Animal Husbandry, Bogor Agricultural University. This research took place from November December 2019 to January - February 2020.

\subsection{Materials}

Equipments for collecting bloods of dairy goats consisted of needle, tube vaccutainer, and syringes. DNA extraction was carried out according to a standard phenol-chloroform procedure. The PCR RFLP tools consisted of eppendorf tubes and tube rack, 1 micropipette unit along with a tip, vortex machine, microsentrifuge (spin down), and incubator, Genotyping tools were thermocycler GeneAmp® PCR ESCO machine, magnetic stirrer, pistil, microwave, 1 set of gel tray, electrophoresis power supply, and UV-transilluminator.

Blood samples in this study were 67 sets of DNAs derived from pure dairy goats namely Peranakan Etawa (PE) (5 males) and Saanen (6 males, 2 females); and their 
crossbreeds namely Sapera (50\% Saanen, 50\% PE) (6 males, 45 females) and SaanPE (75\% Saanen, 25\% PE) (3 males).

The materials used in PCR and electrophoresis processes consisted of extracted DNA, PROMEGA Green PCR Master Mix, Thermo Scientific GeneRuler 100 bp DNA Ladder, forward primer and reverse primer, nuclease free water (NFW), amplicon products, $1.5 \%$ agarose gel, buffer TBE, PeqGreen fluorosafe. Materials used for RFLP and genotyping provided PCR products, enzyme buffers, and DdeI restriction enzymes.

\subsection{Methods}

\subsubsection{Primary Design}

Primers were designed independently based on DNA sequence data from the National Center for Biotechnology Information (NCBI) for goat species or Capra hircus with GenBank access code AJ504710.2 for the CSN1S1 gene at g.12164G>A locus and GenBank access code AJ011018.3 for the CSN2 gene at g.8913C>A locus using the Molecular Evolutionary Genetics Analysis (MEGA7) program.

Primers were designed and their status were checked using a software-based web including: Bioinformatic and Thermofisher scientific multiple primers. Regarding to identification of the single nucleotide polymorphism (SNP) of the CSN1S1_g.12164G>A locus was framed using primers of F: 5 'GGGCTAATCCAAATTCTCTG-3' and R: 3 'GACTCTGTAGAAGGAATCAG-5'. Further the CSN2_g.8913C>A locus was framed by primers of F: 5'GCACAAAGAAATGCCCTTCC-3' and R: 5'GCTATGCTTATTTTGGAACCATTC-3'.

\subsubsection{Blood collection}

Blood sample about $5 \mathrm{~mL}(20 \%)$ of each animal was taken using a needle vaccutainer through the jugular vein which already contained $80 \%$ Absolute Ethanol (EDTA). Blood samples then were stored at $\pm 4^{\circ} \mathrm{C}$.

\subsubsection{DNA extraction}

DNA extraction referred to the method of phenol-chloroform standard [22]. The stages consisted of sample preparation, protein degradation, organic matter degradation, and DNA precipitation. Sample preparation was done for the blood sample put into a $1.5 \mathrm{~mL}$ tube, added with a $0.2 \%$ to $1,000 \mu \mathrm{L} \mathrm{NaCl}$ solution, vortexed, and incubated for 5 minutes. Then the solution was centrifuged at a speed of $8,000 \mathrm{rpm}$ for 5 minutes and the supernatant was removed. Protein degradation was conducted by the blood sample was added with $350 \mu \mathrm{L}$ of tris-EDTA sodium $(1 \times \mathrm{STE}), 40 \mu \mathrm{L}$ SDS $10 \%$, and $10 \mu \mathrm{L}$ prot-K 5 $\mathrm{mg} \mathrm{mL}-1$. Degradation of organic matter was proccessed for the mixture was incubated for 2 hours at $55^{\circ} \mathrm{C}$ under slow shaking conditions.

DNA precipitation was done for the mixture was added with $400 \mu \mathrm{L}$ of phenol solution, $400 \mu \mathrm{L} \mathrm{CIAA}$, and $40 \mu \mathrm{L} 5 \mathrm{M} \mathrm{NaCl}$, then shaken at room temperature for 1 hour. Samples were centrifuged at a speed of $12,000 \mathrm{rpm}$ for 5 minutes. $400 \mu \mathrm{L}$ of supernatant was transferred to a new tube, added $800 \mu \mathrm{L}$ of absolute alcohol and $40 \mu \mathrm{L}$ of $5 \mathrm{M} \mathrm{NaCl}$. The mixture was stored at $-20{ }^{\circ} \mathrm{C}$ overnight, centrifuged at $12,000 \mathrm{rpm}$ for 5 minutes. The precipitate obtained was washed with $800 \mu \mathrm{L}$ of $70 \%$ alcohol, precipitated again and dried, so that the alcohol lost. The DNA precipitate was added with $100 \mu \mathrm{L}$ TE $80 \%$, stored at -20 ${ }^{\circ} \mathrm{C}$, and ready for the uses. 


\subsubsection{Gene Amplification}

Gene amplification used an ESCO GeneAmp® PCR thermal cycler machine. A total of 1 $\mu \mathrm{L}$ of the extracted DNA template was inserted into a PCR tube, added $14 \mu \mathrm{L}$ of premix solution. The PCR premix consisted of $0.2 \mu \mathrm{L}$ of primer (forward and reverse), $7.5 \mu \mathrm{L}$ of PROMEGA Green Master Mix and $6.1 \mu \mathrm{L}$ of nuclease free water (NFW). The mixture was incubated in a thermal cycler for the amplification. The amplification process started with a predenaturation step at $95{ }^{\circ} \mathrm{C}$ for 5 minutes. The second stage consisted of 35 cycles, for each cycle consisting of a denaturation process at $95{ }^{\circ} \mathrm{C}$ for 10 seconds, the primer attachment occurred at $56^{\circ} \mathrm{C}$ for 20 seconds and DNA primer elongation at $72{ }^{\circ} \mathrm{C}$ for 30 seconds. The last step was primary elongation at $72{ }^{\circ} \mathrm{C}$ for 5 minutes.

\subsubsection{Electrophoresis}

The amplified sample was electrophoresed with $1.5 \%$ agarose gel. The gel was made of $0.45 \mathrm{~g}$ agarose gel and $30 \mathrm{~mL} 0.5 \times \mathrm{TBE}$ heated in a microwave at a medium-high temperature $( \pm 3$ minutes). Homogenization was carried out with a magnetic stirrer at a speed of $50 \mathrm{rpm}$ ( \pm 1 minute), then added by $1 \mu \mathrm{L}$ of peqGreen and homogenized for 60 seconds.

The gel was printed on the printer tray and allowed to harden. The hardened gel was transferred to an electrophoresis device, then filled with $5 \mu \mathrm{L}$ amplicon and $2 \mu \mathrm{L}$ thermofisher $100 \mathrm{bp}$ scientific marker. The amplifiers were electrophoresed at a voltage of $100 \mathrm{~V}$ for 35 minutes until the DNA fragments migrated in the gel. The results of the electrophoresis in the form of bands were visible with the help of a UV transilluminator.

\subsubsection{Genotyping}

A total of $5 \mu \mathrm{L}$ of PCR products were added with $0.9 \mu \mathrm{L}$ of NFW, $0.7 \mu \mathrm{L}$ of buffer and 0.4 $\mu \mathrm{L}$ of restriction enzyme DdeI enzyme then incubated at $37^{\circ} \mathrm{C}$ for 4 hours. $7 \mu \mathrm{L}$ of cutting DNA was electrophoresed at a voltage of $100 \mathrm{~V}$ for 35 minutes on $2 \%$ agarose gel. The electrophoretic DNA sample was visualized by means of UV light. DNA fragments emerged from the electrophoresis results were compared with markers to determine the fragment lengths and genotypes.

\subsection{Data analysis}

Genotyping results were calculated for genotype frequency, allele frequency, HardyWeinberg equilibrium value, and heterozygosity observation (Ho) value and expectation (He) value were analyzed by the POPGENE32 software version 1.32. The genotype frequency was a ratio of the number of a certain genotype to the number of the observed population. Genotype frequency and allele frequency were calculated by formula [23]. Hardy-Weinberg equilibrium was tested using the Chi-square $\left(\chi^{2}\right)$ calculation.

\section{Results and Discussion}

\subsection{Genotyping gene}

DNA amplification by Polymerase Chain Reaction (PCR) is a technique that allows enzymatic amplification for certain DNA fragments. Amplification of $\alpha$-S1 Casein gene or CSN1S1 gene amplified the base fragment starting from intron 11 to intron 12 of this gene 
that resulted in a PCR product with a length of $438 \mathrm{bp}$. While amplification of the base fragment of $\beta$-Casein gene or CSN2 gene resulted in a PCR product by $416 \mathrm{bp}$. PCR-RFLP methods for the identification of genotypic variants of both of CSN1S1 gene at g. 12164G $>$ A locus and CSN2 gene at g.8913C > A locus were restricted by DdeI enzyme. The DdeI is a purified endonuclease enzyme from an escherichia coli strain carrying the DdeI desulfovibrio desulfuricans gene. This enzyme acts at a temperature of $37^{\circ} \mathrm{C}$. The DdeI restriction enzyme recognized the base cutting site at 5'-C|TNAG-3' sequences in both CSN1S1 and CSN2 genes.

Genotyping the CSN1S1_g.12164G>A locus of dairy goats observed resulted in three genotypes, namely GG, GA, and AA (Figure 1). Homozygous GG genotype presented three fragments (192 bp, $145 \mathrm{bp}$ and $101 \mathrm{bp}$ ), heterozygous GA genotype generated four fragments (337 bp, $192 \mathrm{bp}, 145 \mathrm{bp}$ and $101 \mathrm{bp}$ ), and AA genotype exhibited two fragments (337 and $101 \mathrm{bp}$ ). The AA genotype occurred by the existing a base transition of Guanine to Cytosine $(\mathrm{G}>\mathrm{A})$ at a base 14 in exon 12 of the CSN1S1 gene [16, 24]. This base transition replaced a purine base to another purine base (adenine to guanine) or a pyrimidine base to another pyrimidine base (thymine to cytosine). The base substitution mutations in the coding sequence (CDS) region were able to be classified according to their effect on amino acids. A mutation was defined as non-synonymous when a base mutation at a specific point changed the original codon leading into the changes of amino acids [25]. The A allele, which in this case was a mutation in CDS at g.12164G>A locus, changed the amino acid of Arginine (Arg100) to Lysin (Lys) [16]. Non-synonymous mutation at this base point caused casein deficit in cheese yields by $5-7 \%$ in heterozygous condition [7].

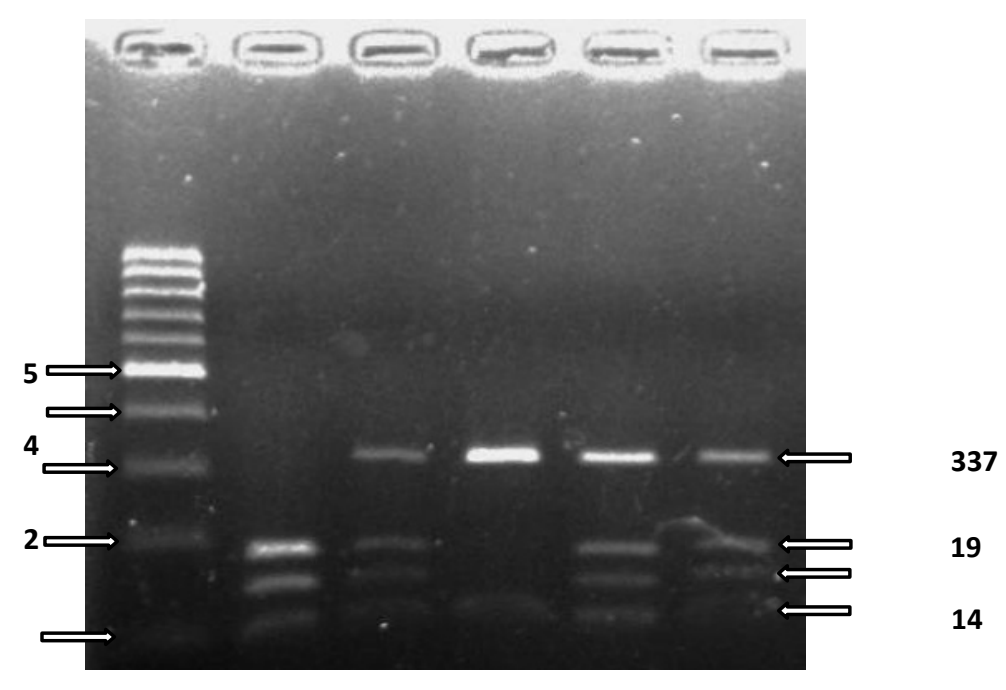

Fig. 1. Genotyping results of the PCR products of the $\alpha$-S1 Casein gene at g.12164G>A locus with DdeI restriction enzyme in agarose gel 2\% PeqGreen staining. (M: marker $100 \mathrm{bp}$, molecular ladder promega and GG, GA, and AA genotypes

Further genotyping results of the base cutting site by the DdeI enzyme to the base sequences of 5'-C|TNAG-3' in exon 7 of the $\beta$-Casein gene or CSN2 gene at g.8913C>A locus generated two fragments (233 bp and $162 \mathrm{bp}$ ) known as CC genotype. One base fragment by 21 bp run out, so that band was not seen on the electrophoresis gel. Genotyping of the CSN2_g.8913C>A locus for all dairy goats evidently resulted in only 
the CC genotype, without the two remaining AA genotype (416 pb) and AC genotype (416 $\mathrm{pb}, 233 \mathrm{bp}$, and $162 \mathrm{bp}$ ). The CSN2*E allele was previously identified as a base mutation at the g.8913 locus in exon 7 of this gene and reported as a transversion mutation on the base sequences of TCT|TAT. The base mutation was responsible for the changes of amino acid Ser166 to Tyr166 in the complete protein $[12,19]$.

\subsection{Genotype and Allele Frequenciest}

Genotyping results on the base sequences of 5'-C|TNAG-3' of the CSN1S1 gene at g.12164G $>$ A locus for all dairy goats are presented in Table 1. Pure PE goat presented the same frequencies for AA and GA genotypes instead of a lower frequency for the GG genotype. Meanwhile pure Saanen goat generated a high frequency of the GA genotype than the GG genotype without the AA genotype. However, Sapera and Saanpe cross goats presented quite different genotype frequencies compared to those of the two pure dairy goats. Sapera goats (50\% saanen, 50\% PE) yielded the highest frequency of the GA genotype, followed by the GG genotype, and the lowest for the AA genotype. Whereas the SaanPE goat (75\% Saanen, 25\% PE) delivered a high frequency of the AA genotype in the opposite a low frequency of the GG genotype and without the AG genotype. Genetic polymorphism of CSN1S1_g.12164G>A locus was caused by a transitional mutation of the g.12164G>A SNP [16].

Table 1. Genotype and allele frequenciest of the CSN1S1 gene at g.12164G>A locus and the CSN2 gene at $\mathrm{g} .8913 \mathrm{C}>\mathrm{A}$ locus of pure and cross dairy goats

\begin{tabular}{lcccccc}
\hline Dairy goat type & $\mathrm{N}$ & \multicolumn{5}{c}{ Frequency } \\
\cline { 3 - 7 } & \multicolumn{5}{c}{ Genotype } \\
\hline CSN1S1_g.12164 & GG & GA & AA & G & A \\
G>A locus & & & & & & \\
\hline PE & 5 & $0.200(1)$ & $0.400(2)$ & $0.400(2)$ & 0.400 & 0.600 \\
Saanen & 8 & $0.250(2)$ & $0.750(6)$ & $0.000(0)$ & 0.625 & 0.375 \\
Sapera & 51 & $0.353(18)$ & $0.451(23)$ & $0.196(10)$ & 0.578 & 0.422 \\
SaanPE & 3 & $0.333(1)$ & $0.000(0)$ & $0.667(2)$ & 0.333 & 0.667 \\
\hline CSN2_g.8913 & & CC & CA & AA & C & A \\
C $>$ A locus & 5 & $1.0(5)$ & $0.0(0)$ & $0.0(0)$ & 1.000 & 0.000 \\
PE & 8 & $1.0(8)$ & $0.0(0)$ & $0.0(0)$ & 1.000 & 0.000 \\
Saanen & 51 & $1.0(51)$ & $0.0(0)$ & $0.0(0)$ & 1.000 & 0.000 \\
Sapera & 3 & $1.0(3)$ & $0.0(0)$ & $0.0(0)$ & 1.000 & 0.000 \\
SaanPE &
\end{tabular}

Note: $\mathrm{N}$ for number of samples, (...) for samples of possessing a certain genotype

Genetic diversity could be determined by the probability of the changing of an allele to another different form due to mutation within one generation [26]. It is said [23] that a population is said to be diverse if there are two or more alleles. Genotype frequenciest of those AA, AG, and GG genotypes of the g.12164G>A locus of the CSN1S1 gene across the dairy goats were diverse. Distribution of the GG genotype frequenciest from the highest was successively for Sapera (0.353), SaanPE (0.333), Saanen (0.250) and PE (0.200). Meanwhile distribution of the GA genotype frequenciest from the highest was successively for Saanen (0.750), Sapera (0.451), PE (0.400), and SaanPE (0.000). While distribution of the AA genotype frequenciest from the highest was succesively for SaanPE (0.667), PE (0.400), Sapera (0.196) and Saanen (0.000). Genotype frequenciest seemed to 
be different depending on the number of samples tested [27]. The frequenciest of alleles and genotypes can change due to natural selection and evolutionary forces, including mutations, migration (gene flow), non-random mating, genetic drift.

By contrast, the CSN2 gene at g.8913C >A locus was found that all goats had only the $\mathrm{G}$ allele (100\%) without the A allele. Therefore the g.8913C>A locus of this gene was monomorphic across dairy goats. According to [21] a population was polymorphic for the owning multiple alleles (more than 1 allele) in one locus with an allele frequency of less than $0.99(99 \%)$. According to [28] $\beta$-casein as the main casein fraction in dairy goat milk was known to be more monomorphic. However, in some cases there were polymorphisms in different alleles such as A, C, CI alleles in Girgentana goat breed [10]. CSN2 genetic polymorphisms were found in Banat White and Carpatina goat breed [18]. While variations in the E allele occurred in Frisa goat breed with the allelic frequency of $7.9 \%$ and the heterozygosity value of 0.0534 [12]. Allele E polymorphisms of the CSN2 gene were found in Piemontese cattle breed [29].

\subsection{Heterozygosity and Hardy-Weinberg Equilibirium Values}

Heterozygosity is one parameter that can be used to estimate the level of genetic variation in a population. If the observed heterozygosity $(\mathrm{Ho})$ value is close to 0 meaning a low heterozygosity degree instead of high heterozygosity degree for that value close to 1 . The observed heterozygosity (Ho) value and the expected heterozygosity $(\mathrm{He})$ value of the CSN2 gene at g.12164G>A locus are presented in Table 2. Whilst the CSN2 gene at g.8913C > A locus of all dairy goats had only the CC genotype (100\%) leading to the only C allele $(100 \%)$. The heterozygosity observation values therefore were 0 or monomorphic for all of the dairy goats observed.

Table 2. The observed heterozygosity (Ho) and the expected heterozygosity (He) values of the CSN1S1 gene at g.12164G >A locus of pure and cross dairy goats

\begin{tabular}{lcccc}
\hline Dairy goat & $\mathrm{N}$ & Ho value & He value & $\mathrm{X}^{2}$ test \\
\hline Sapera & 51 & 0.450 & 0.490 & $0.370^{\text {tn }}$ \\
Saanen & 8 & 0.750 & 0.500 & $2.333^{\text {tn }}$ \\
SaanPE & 3 & 0.000 & 0.500 & - \\
PE & 5 & 0.400 & 0.533 & $0.400^{\text {tn }}$
\end{tabular}

Note: $\mathrm{N}=$ number of samples, $\mathrm{He}=$ heterozygosity expectation, Ho = heterozygosity observation, $\mathrm{ns}=$ not significant $(\mathrm{P}>0.05), \chi^{2}$ calculation $<\chi^{2}$ table $\left.(\mathrm{P} 0.05 ; 1)=3.84\right)$.

Table 2 shows the heterozygosity level from the highest one successively for Saanen (0.75), Sapera (0.450), and PE (0.400), whilst SaanPE goat was monomorphic (0.000). This indicated that SaanPE goat had a very close genetic relationship. However, the calculation of the heterozygosity values especialy in SaanPE, PE, and Saanen dairy goats came from very limited sample numbers. The results of Hardy-Weinberg equilibrium by Chi-Square $\left(\mathrm{X}^{2}\right)$ testing at g. 12164G>A locus showed that Sapera (0.370), Saanen (2.333) and PE (0.400) goats were in the Hardy-Weinberg equilibrium $\left(\mathrm{X}^{2}\right.$ count smaller than $\mathrm{X}_{2}$ table $\left(\mathrm{P}_{<0.05 ; 1}\right)$ by 3.84. By contrast SaanPE goat was in the Hardy-Weinberg disequilibrium $\left(\mathrm{X}^{2}\right.$ count $)$ larger than $\left(\mathrm{X}_{2}\right.$ table $\left.{ }_{\mathrm{P} 0.05 ; 1}\right)$ by 0.05 . One of the conditions causing in the Hardy-Weinberg disequilibrium according to [30] was due to natural and assortative mating. The H-W equilibrium of the genotype frequenciest in Sapera, Saanen and PE dairy goats could be an indicator for no selection on the CSN1S1 gene of the g. 12164G>A SNP within these dairy goats. The equilibrium can occur in the absence of mutation, natural selection, genetic drive, migration and assortative mating. 


\section{Conclusion}

The CSN1S1 gene at g.12164G>A locus in pure and cross dairy goats resulted in three genotypes of AA (0.196-0.667), GA (0.400-0.750), and GG (0.200-0.353) but without AA genotype in Saanen and GA genotype in SaanPE. Saanen goat had the highest heterozygosity degree, while SaanPE goat was in Hardy-Weinberg disequilibrium. By contrast, the CSN2 gene at g.8913C>A locus was monomorphic for all dairy goats for possesing only CC genotype and C allele. The CSN1S1 gene of g.12164G>A SNP could be potencial to be considered as a marker assisted selection for genetic improvement of protein fractions in dairy goats.

High appreciation is delivered to the Division of Animal Breeding and Genetics, Department of Animal Production Science and Technology, Faculty of Animal Science IPB that has provided in kind assistance in this research collaboration as stated in the Decree of the Head of IRIAP No. 143/Kpts/OT 210/ H.5.2/ 04/2020.

\section{References}

1. A. Anggraeni, L. Praharani. Morphometric characteristics of Etawah Grade goat as a female population of crossed Sapera dairy goat at IRIAP, in Proceedings of PERIPI2017 International Seminar October 2 nd 2017, Bogor, Indonesia (2017).

2. A. Kocak, T. Sanli, E.A. Anli, A.A. Hayaloglu. 2020. Role of using adjunct cultures in release of bioactive peptides in whitebrined goat-milk cheese. Food Sci. Tech. (2020).

3. L. Ferretti, P. Leone, V. Sgaramella. Long range restriction analysis of the bovine casein genes. Nuc. Acids Res. 18 (1990).

4. Roginski H. 2003. Encyclopedia of dairy sciences. London (UK): Academic Press.

5. H.M. Farrell, R. Jimenez-Flores, G.T. Bleck, E.M. Brown, J.E. Butler, L.K. Creamer, C.L. Hicks, C.M.K.F. Hollar, Ng-Kwai-Hang, H.E. Swaisgood. Nomenclature of the proteins of cows' milk-Sixth revision. J Dairy Sci. 87 (2004).

6. D. Guan, E. Marmol-Sanchez, T.F. Cardoso, X. Such, V. Landi, N.R. Tawari, M. Amills. Genomic analysis of the origins of extant casein variation in goats. J Dairy Sci. 102(6) (2019).

7. S. Mastrangelo, M.T. Sardina, M. Tolone, B. Portolano. Gen polymorphism at the CSN1S1 gen in Girgentana dairy goat breed. Anim Prod Sci.53(5) (2013).

8. M. Rijnkels, P.M. Kooiman, H.A. deBoer, F.R. Pieper. Organization of the bovine casein gene locus. Mammalian Gen. 8 (1997).

9. A,S.E. Galila, S.F. Darwish. A PCR-RFLP assay to detect genetic variants of kappacasein in cattle and buffalo. Arab J Biotech. 11 (2008).

10. D.W. Threadgill, J.E. Womack. Genomic analysis of the major bovine milk proteins genes. Nucl Acids Res. 18 (1990).

11. A.L.S. Azevedo, C.S. Nascimento, R.S. Steinberg, M.R.S. Carvalho, M.G.C.D. Peixoto, R.L. Teodoro, R.S. Verneque, S.E.F. Guimarães, M.A. Machado. Genetic polymorphism of the kappa-casein gene in Brazilian cattle. Gen Mol Res. 7 (2008).

12. A. Caroli, F. Chiatti, S. Chessa, D. Rignanese, P. Bolla, G. Pegnacco. Focusing on the goat casein complex. J. Dairy Sci. 89 (2006). 
13. B.S. Dagnachew, G. Thaller, S. Lien, T. Ådnøy. Casein SNP in Norwegian goats: additive and dominance effects on milk composition and quality. Genetics Selection Evolution 43 (31) (2011).

14. P. Martin, M. Ollivie-Bousquet, F. Grosclaude. Genetic polymorphism of caseins: a tool to investigate. Int Dairy J. (1999).

15. Z.H. Fang, H. Bovenhius, H.J.F. van Valenberg, P. Martin, T. Huppertz, H.P.W. Visker. Genetic parameters for $\alpha S 1$-casein and $\alpha S 2$-casein phosphorylation isoforms in Dutch Holstein Friesian. J Dairy Sci. 101(2) (2019).

16. G. Cozenza, P.D. Pauciullo, L. Colimoro, A. D’Avino, L. Mancusi, L. Ramunno. Genotyping at the CSN1S1 locus by PCR-RFLP and AS-PCR in a Neapolitan goat population. Small Rum. Res. 74 (2008).

17. N.A.M. Eskin, H.M. Handerson, R.J. Townsend. Biochemistry of foods. New York (USA): Academic Press, Inc (2013).

18. S. Kusza, D.E. Ilie, M. Sauer, K. Nagy, I. Patras, D. Gavojdian. Genetic polymorphism of CSN2 gene in Banat white and carpatina Goats. Acta Biochim. 63 (2016).

19. L. Tortorici, R.D. Gerlando, S. Mastrangelo, T. Maria, Sardina, B. Portolano. Genetic Characterisation of CSN2 Gene in Girgentana Goat Breed. Italian J. of Anim. Sci. 13(3414) (2014).

20. P.V. Vinesh, Brahma, Biswajit, Kaur, Rupinder, Datta, Tirtha Kumar, Goswami, Surender, De, Sachinandan. Characterization of $\beta$-casein gene in Indian riverine buffalo. Gene 527(2) (2013).

21. L.V. Singh, S. Jayakumar, A. Sharma, S.K. Gupta, S.P. Dixit, N. Gupta, S.C. Gupta. Comparative screening of single nucleotide polymorphisms in $\beta$-casein and $\kappa$-casein gene in different livestock breeds of India. Meta Gene 4 (2015).

22. J. Sambrook, D. Russel. Molecular Cloning: A Laboratory Manual. New York (US): Cold Spring Harbor Laboratory Pr. (2001).

23. M. Nei, S. Kumar. Molecular Evolution and Phylogenetics. New York (US): Oxford Univ Pr. (2000).

24. I.J. Giambra, L. Chianese, P. Ferranti, G. Erhardt. Short communication: Molecular genetic characterization of ovine aS1-casein allele $H$ caused by alternative splicing. $\mathrm{J}$ Dairy Sci. 93 (2010).

25. D. Graur. Nature Encyclopedia of The Human Genome.Single base mutation. Israel (IL): Macmilian Publisher Ltd. (2003).

26. A.J.F. Griffths, J.H. Miller, D.T. Suzuki, R.C. Lewontin, W.M. Gelbart. An introduction to genetic analysis, $7^{\text {th }}$ edition. New York (US): WH Freeman Company. (2000).

27. C.F. Aquadro. Encyclopedia of Genetics: Gene frequency. London (UK): Academic Pr. (2001).

28. D. Marletta, A. Criscione, S. Bordonaro, A.M. Guastella, G. D'Urso. Casein polymorphism in goat's milk (Review). Lait 87 (2007).

29. E. Marsella, S. Piva, F. Giacometti, G. Liuzzo, A.V. Zambrini, A. Serraino. Evaluation of bovine beta casein polymorphism in two dairy farms located in northern 
Italy. Italian J. Food Safety. 6(6904) (2017).

30. J.E. Wigginton, D.J. Cutler, G.R. Abecasis. A Note on Exact Tests of Hardy-Weinberg Equilibrium. Am. J. Hum. Genet. 76 (2005). 